\title{
Len Hansa Christiana Andersena - opowieść fantastyczna o roślinie?
}

Hans Christian Andersen's The Flax - a fantasy tale about a plant?

Abstract: The article discusses The Flax, a fantasy tale by Hans Christian Andersen. In my reading, I focus on details of the tale's text. I point out various contexts that expand and diversify the reading of the tale, such as: cultural, religious, biblical, artistic, literary and cinematic ones.

Keywords: Andersen, fairy tale, cultural contexts, fantasy genre, plants

Nazwy roślin pojawiają się w około dwudziestu tytułach opowieści Andersena (np. Przebiśnieg, Ostatni sen starego dębu). Rośliny są także obecne w świecie przedstawionym, nawet jeśli nie są wymienione w tytule (np. Królowa Śniegu, Są różnice), stając się mówiącymi bohaterami. Andersen w krótkich opisach kwiatów czy drzew wskazuje z zachwytem najważniejsze składniki wyglądu. Przedmiotem opisu jest na przykład gałązka jabłoni, kwiat dmuchawca i ostu czy gryka. W wielu opowieściach pojawia się motyw płótna oraz papieru, otrzymywanego na przykład ze szmat, na które wcześniej przetworzono rośliny, ale przede wszystkim motywy opowieści na takim papierze zapisywanych. Poniżej kilka przykładów.

Kwiat ostu w Co przeżył oset stanowi ozdobę ubrania młodego chłopca, inspiruje do zaprojektowania i wykonania ramy lustra, ale co najważniejsze, cały krzew ostu „wchodzi” do ponadczasowej opowieści Oto i ona! (Andersen, 2006c, s. 246): „[...] krzew ostu ze swoimi różowofioletowymi, grubymi koszyczkami kwiatów [...] dno kwiatu wielkie jak u karczocha wyglądało jak posrebrzony słonecznik" (Andersen, 2006c, s. 243, 245). W Kotnierzyku "Szmaty zamieniły się w biały papier, a kołnierzyk stał się tą właśnie kartką papieru, którą tu widzimy, to na niej wydrukowana jest ta historia" (Andersen, 2006a, s. 447).

Przedmiotem opisów w opowieści Gryka są wierzba, tytułowa roślina, zboża: „To czcigodna, wielka wierzba, ale przykurczona i stara, pęknięta przez śro- 
dek, a $\mathrm{z}$ tego pęknięcia wyrastają trawy i pędy jeżyn; drzewo pochyla się, gałęzie zwisają nad samą ziemią, wyglądają jak długie, zielone włosy" (Andersen, 2006a, s. 258). Wygląd wierzby ironicznie komentuje gryka: „[...] aż mu [drzewu - E.O.] trawa rośnie w brzuchu!” (s. 258). O owsie czytamy: „[...] cudowny owies, który gdy jest dojrzały, wygląda jak cała chmara maleńkich żółtych kanarków na gałęzi” (s. 258).

Len - opowieść fantastyczna Andersena ukazała się w czasopiśmie w kwietniu 1849 roku (tuż po czterdziestych czwartych urodzinach pisarza). Tytuł wskazuje i na pojedynczą roślinę, i na zbiór roślin o takich samych właściwościach przyrodniczych. Można by mówić o metonimii i personifikacji jednego elementu zbioru, czemu sprzyja także forma rzeczownika „len”, który nazywa także tkaninę oraz wszystko, co jest z niej wykonane.

Andersen przez wiele lat tworzył za pomocą wielkich nożyczek różnego rodzaju wycinanki. Wśród nich jest wycinanka z 1848 roku, przechowywana w Bibliotece Królewskiej w Kopenhadze, zatytułowana Botanik ${ }^{1}(18,5 \times 26,0 \mathrm{~cm})$ i dedykowana ówczesnemu duńskiemu przyrodnikowi Johanowi Langemu. Wycinance przypisano też inny tytuł The flower $\mathrm{man}^{2}$. Widzimy figurę ułożoną $\mathrm{z}$ łodyżek i liści, jakby rycerza, kogoś w butach z ostrogami do jazdy konnej, z twarzą jakby słońcem lub twarzą kwiatem, otoczoną płatkami, z sercem pośrodku. Wycinanka powstała w 1848 roku, kiedy Andersen przebywał u Ingemannów w Sorø, a Johan Lange był wtedy wykładowcą na tamtejszej uczelni; potem został profesorem w Królewskim Instytucie Weterynarii i Rolnictwa. Znawca dzieła Andersena Johan de Mylius komentuje, że wycinanka powstała w czasie smutku i żałoby z powodu wojny trzyletniej (tzw. pierwsza wojna o Szlezwik; 18481850). Napisał, że jest zabawna i pozytywna (funny and positive) i jest właściwą wycinanką dla właściwego człowieka (the right cutting for the right man).

W opowieści Len mówią: narrator oraz upersonifikowane roślina, drewniane kołki, papier, iskierki ognia i małe istotki.

Len stał w pełnym kwieciu. [...] I tak było z lnem.

Andersen, 2006a, s. 450-453

Len na początku jako kwitnąca roślina czuje się trochę jak małe dziecko. Cieszy się z niebieskich kwiatków, które są delikatniejsze od skrzydeł moli³. Przy-

\footnotetext{
${ }^{1} \mathrm{http} / / /$ allinfo.space/2018/10/19/the-paper-cuts-of-hans-christian-andersen/ [data dostępu: 5.03.2020].

2 https://books.google.pl/books?id=WDWIDwAAQBAJ\&pg=PT235\&lpg=PT235\&dq= the+botanist+by+andersen + paper+cut+lange\&source=bl\&ots=OkzabPl9Nr\&sig=ACfU3U2Zy bwqhxh_0v5RaXAVnUJyzoXTBw\&hl=pl\&sa=X\&ved=2ahUKEwiGsJnhwtDnAhXEzKQKHRG ODUEQ6AEwC3oECAYQAQ\#v=onepage \&q=the $\% 20$ botanist $\% 20$ by $\% 20$ andersen $\% 20$ paper $\% 20$ cut\%20lange \&f=false [data dostępu: 5.03.2020].

${ }^{3}$ W nowej edycji, w której baśń jest opowiedziana, czytamy o kwiatach tak delikatnych jak motyle skrzydła. Zwyczajny i uciążliwy owad został zastąpiony wyżej cenionym motylem. Nie wydaje się jednak, aby ta zmiana była konieczna. Delikatność można przypisać każdym skrzydłom.
} 
jemne są jego doznania związane ze słońcem i z deszczem. Wydaje się, jakby był dzieckiem wykąpanym, a następnie ucałowanym przez matkę, tkwiącym w bezpiecznym świecie dzieciństwa.

O kwitnącym na niebiesko polu lnu jest współczesny wiersz Uładzimira Filipowicza Len:

Za naszym miastem,
To ujrzeć trzeba,
Len już wyrasta
I kwitnie niebem.
Niesamowite
- Cuda bez końca,
Len swym błękitem
Z niebem się złączył.
Filipowicz, 2006, s. 10
[...] będzie ze mnie kawał płótna! [...] Jestem bezgranicznie szczęśliwy, naj-
szczęśliwszy!

Andersen, 2006a, s. 450

Roślina ma świadomość, że to dopiero początek życia i że będzie z niej „wspaniały kawałek płótna!”. Wie, czym się stanie, i z tego powodu czuje się bardzo szczęśliwa. Andersen hiperbolizuje to poczucie szczęścia, powtarzając słowo „szczęśliwy”, stopniując przymiotnik i dodając przysłówek.

[...] odezwały się kołki w płocie.

Andersen, 2006a, s. 450

Motyw mówiących kołków potraktowany jest nieco ironicznie, czy wręcz prześmiewczo; wiedzą, bo mają sęki, czyli są stare. Kołki śpiewają, trzeszcząc, krótki tekst dziecięcej rymowanki: „Nie do wiary, / czary-mary / i skończona pieśń". To prawda, dzieją się cuda, ale jak się okaże, pieśń się nie kończy.

[...] przyszli ludzie, chwytali len i wyrywali go z korzeniami, oj, bolało [...] to było straszne! [...] potem stał się dużym, pięknym kawałkiem płótna.

Andersen, 2006a, s. 450-451

Andersen wylicza skrótowo etapy obróbki lnu, nazywa cierpienie rośliny i jej postawę wobec bólu. Len trzeba wyrwać z ziemi, aby nie uszkodzić łodygi, moczyć, suszyć, łamać i zgniatać, aby oddzielić włókna od paździerzy, czesać i na kołowrotku prząść kądziel, aby otrzymać nici, z których można utkać materiał na krosnach ${ }^{4}$. Roślina $\mathrm{z}$ opowieści cierpi, ale myśli, że trzeba przetrwać takie

${ }^{4}$ Do czynności związanych z uprawą lnu nawiązano w teatrze Atofri w spektaklu dla małych dzieci. Zob. rec. http://teatratofri.pl/wp-content/uploads/2017/02/Len_recenzja_Small_Size_Days_ 2017.pdf_[data dostępu: 5.03.2020]. 
działania, a nawet znaleźć w tym radość, przekonuje siebie, że tak bywa i trzeba się cieszyć - „Trzeba cieszyć się z tego, co się ma. Cieszyć się, cieszyć! [...] Jestem najszczęśliwszy w świecie! Taki mocny i taki miękki, taki biały i taki długi! To coś innego niż być tylko rośliną, nawet jeśli ma się kwiaty!” (Andersen, 2006a, s. 450-451).

Nastąpiła przemiana lnu (nie ostatnia) rośliny w kawałek białego płótna. Len czerpie $\mathrm{z}$ tego faktu wiele radości; wydaje mu się, że jest kimś lepszym, chociaż nadal ma związek z rośliną.

Jak je cięto, jak przecinano, jak kłuto igłami [...] z płótna zrobiono dwanaście sztuk bielizny [...].

Andersen, 2006a, s. 451

Zaskakuje wybór akurat bielizny jako rzeczy wykonanych z płótna. Len jest tkaniną wykorzystywaną do szycia rozmaitych elementów ubioru, a także na przykład do ubierania zmarłych. Być może, bielizna nasuwa skojarzenia erotyczne czy nawiązuje do ubierania żołnierzy w czasie wojny? W każdym razie len się cieszy, że jest pożyteczny — „użytecznym trzeba być, to czysta przyjemność”: „...] bielizna zaczęła się drzeć. [...]. I podarto ją na kawałki i strzępy [...] aż zamieniła się w cudowny, cienki papier listowy” (Andersen, 2006a, s. 451).

Z lnu można rzeczywiście wytwarzać najlepszy papier, na przykład czerpany. Bohater opowieści czuje się lepszy niż przedtem. Po raz kolejny doznanie bólu poprzedziło przemianę. Wartość papieru wynika nie tylko z tego, że jest dobrej jakości, lecz że można na nim zapisywać historie - „było to słuszne i dobre, czyniło ludzi lepszymi i mądrzejszymi” (Andersen, 2006a, s. 451-452).

$\mathrm{W}$ monologu lnu pojawiają się treści religijne, przede wszystkim zawierzenie Bogu — „On prowadzi mnie od jednej radości do drugiej”: „[...] będę przynosił ludziom szczęście i wiedzę. [...] Bóg wie, że sam niczego nie dokonałem poza tym, co korzystając z okazji, musiałem robić, żeby istnieć” (Andersen, 2006a, s. 452).

Len cieszy się, że może oddziaływać na ludzi, na czytelników opowieści. Swoją historię podsumowuje jako trwanie w wyznaczonych przez Boga rolach: „Ja zostanę, a po świecie będą krążyć książki. [...] To bardzo słuszne, można zebrać myśli i zastanowić się nad tym, co się ma w środku” (Andersen, 2006a, s. 452).

Rękopis napisany na papierze $\mathrm{z}$ lnu został odłożony na półkę. W świat, po którym Andersen tak lubił podróżować, wysłano wydrukowane książki. Dla bohatera opowieści, wydaje się, nastaje czas uspokojenia, który może wykorzystać do poznania samego siebie, ale bohater przeczuwa nowe zdarzenia - „coś nowego, zawsze jest coś nowego!":

[...] i w tej samej chwili stał się jednym wielkim płomieniem; strzelał w powietrze tak wysoko, jak len nigdy nie potrafił unieść swoich błękitnych kwiat- 
ków, i lśnił, jak nigdy nie lśniło białe płótno; wszystkie zapisane literki w jednej chwili stały się czerwone, a słowa i myśli zapłonęły. Teraz idę prosto do słońca!

Andersen, 2006a, s. 453

Wydaje się, że mimo niszczącej siły ognia historia osiąga punkt kulminacyjny. Widok jest piękny, wszystko zmierza ku słońcu, ku górze, ku Bogu. Pozostaje nie tylko popiól, ale także czerwone iskierki i maleńkie istotki, które polemizują ze zdaniem z rymowanki: „Ale maleńkie, niewidzialne istoty mówiły tak: — Pieśń nigdy się nie kończy! To jest w tym wszystkim najcudowniejsze! Wiem o tym dobrze i dlatego jestem najszczęśliwszy!” (Andersen, 2006a, s. 453).

Zwraca uwagę przejście od rzeczy widzianych (niebieskie kwiaty lnu) do tego, co niewidzialne, co kryje tajemnicę, ale ma moc, czyli do słów. Ciekawa jest zmiana liczby: mówią, a właściwie wykrzykują istotki, ale w eksklamacjach powraca ,ja”, czyli upersonifikowany len. Cała opowieść potwierdza też tezę, że w całości zawiera się wiele elementów, a w każdym elemencie jest istota całości. Tytułowy len stanowi zbiór roślin, ale i pojedynczą roślinę. W iskierkach ognia i niewidzialnych istotkach też tkwi „ziarnko” lnu, który był ogniwem w procesie nieustannie zachodzących przemian.

Ale tego dzieci nie mogły ani usłyszeć, ani zrozumieć, bo też nie o to chodzi, dzieci nie muszą wszystkiego wiedzieć.

Andersen, 2006a, s. 453

W końcowym zdaniu opowieści ujawnia się narrator, który kieruje słowa do dorosłego odbiorcy czytającego dziecku, ale być może też do dzieci, zachęcając je do zgłębiania tajemnic istnienia w świecie. Dorosły zrozumie to, czego dzieci nie zrozumiały, ale one też mogą się nad sensem opowieści zastanawiać, a zrozumieją, kiedy będą starsze. Może trochę dziwna ta historia rośliny, jakby niekonsekwentna. Zdziwienie budzi motyw bielizny. Dominuje przejście od widzialnych, zmysłowo doświadczanych elementów do abstrakcji — w słowach czy historiach i książkach lub pieśni.

Andersen przekonuje, że istnieć to podlegać nieustannym przemianom, znosić cierpienia i ból, jeśli taka ma być cena za osiągnięcie wyższego poziomu rozwoju. Len „powtarza” - jest mi dobrze; coś ze mnie będzie; jestem czymś; jestem użyteczny; jestem czymś lepszym; zastanawiam się nad sobą. Przyjmuje optymistyczną postawę życiową - we wszystkim można odnaleźć sens; w każdej sytuacji można wierzyć w zmianę na lepsze i być po prostu szczęśliwym, bo doznaje się pierwotnych bodźców: słońca, ciepła lub wody, bo jest się potrzebnym, bo służy się wyższym celom, odczuwa się wzrost poziomu duchowości, łączność z Bogiem i innymi ludźmi. Fortuna kołem się toczy, cierpienie towarzyszy przemienianiu się; podlegając przemianie, zachowuje się własną istotę. 
Andersen z zainteresowaniem i zachwytem patrzy na świat wokół siebie, w tym także na rośliny, drzewa i kwiaty. Ponieważ jest myślicielem, w świecie zewnętrznym dostrzega analogie do własnych lub cudzych losów i emocji. Nie inaczej jest w Lnie. Wypowiedzi antropomorfizowanego lnu zawierają ocenę dramatycznej sytuacji czy wręcz tragicznego położenia cierpiącej istoty, poddawanej przemocy, oraz sugestie, jaką można przyjąć postawę wobec takich faktów, w czym upatrywać nadziei i szukać sensu. Napisane jest empatycznie, z czułością. Czytać też trzeba z empatią i czułością. Natura personifikowana - to nie tylko chwyt literacki, to też spojrzenie z czułością na przyrodę.

Zauważamy w opowieści powtarzalność elementów, które siebie nawzajem przypominają. Trafiają się żywioły: ziemia, powietrze, woda, ogień; przewija się kilka barw: niebieska (ukryta, nienazwana zieleń), biel, czerwień (nienazwana czerń); dochodzi do zmiany w zakresie liczby elementów, zbiorów i jednostek. Znajduje wyraz przekonanie, że całość zawiera się w cząstkach, cząstki tworzą całość: len - niebieskie kwiatki; ogień - czerwone iskierki, maleńkie, niewidzialne istotki (jak ta wielość kwiatów); len - pole lnu; pojedyncza roślina (zwłaszcza na końcu — „jestem najszczęśliwszy”); płótno - dwanaście sztuk bielizny; papier - luźne kartki; historie - myśli i słowa.

W jungowskich interpretacjach opowieści Andersena w pracy Agnieszki Miernik Len pojawia się dwukrotnie - w rozdziale o dziecku oraz w rozdziale o cieniu i wędrujących duszach. W początkowych zdaniach Lnu badaczka dostrzega motywy światła, ciepła i miłości, które wypełniają liryczny obraz mitycznego dzieciństwa:

[...] budują elementy ulotności, delikatności, len choć przytwierdzony do ziemi wydaje się wolny, niemal unosi się w powietrzu, wrażenie to potęgują powtórzenia, „jestem szczęśliwy, najszczęśliwszy”. Obraz beztroski dzieciństwa dopełnia element wody ujęty w formę ożywczego deszczu oraz matczyny całus.

Miernik, 2015, s. 20

Andersenowskie opisy etapów obróbki lnu łączy Miernik z cyklem inkarnacji i odnalezieniem indywidualnego sensu. Roślina poddawana jest próbom wody, ognia, łamania, zgniatania i czesania ${ }^{5}$. Stan rozbicia osobowości pogłębia podział kawałka płótna na dwanaście elementów, ale jednocześnie len, dostrzegając przeciwieństwa, mówi też o jedności ${ }^{6}$. Z kolei, wydawałoby się, unicestwienie lnu podczas spalenia okazuje się zgodnie z Tybetańska księga umarłych jeszcze innym wcieleniem i formą zachowania nieśmiertelności (len rozbity na maleńkie istoty): „Len zgłębił wieloaspektowość życia i śmierci, rozpoznał transcendentny

${ }^{5}$ W buddyzmie pięć elementów budujących życie na ziemi: ziemia, woda, ogień, powietrze, przestrzeń.

6 Liczba „12” symbolizuje porządek kosmiczny, harmonię, radość; czas potrzebny do zmian; sześć podwójnych części ciała: oczy, uszy, nozdrza, wargi, ręce i nogi. 
wymiar istnienia, a koncentrując się na kontemplowaniu buty, potrafił dostrzec w każdej stracie początek zysku [...]” (Miernik, 2015, s. 84-85).

Na stronie Centrum Hansa Christiana Andersena wymieniono trzy moty-

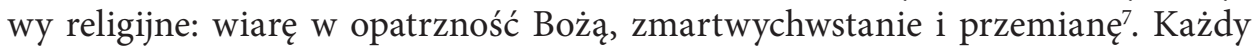
z motywów został wyjaśniony i wskazany we fragmentach opowieści.

Len występuje w znakomitych, pośmiertnie wydanych rozważaniach Roberta Eislera oraz Waltera Hidburgha ${ }^{8}$, który sięga do tekstów antycznych i szuka zapisów smutnej, żałobnej pieśni Linos. Eisler nawiązuje też do postaci grajka na tarczy Achillesa. Wskazuje postać o imieniu Linos w mitologii greckiej (syn Psamate i Apollina; muzyk i nauczyciel Heraklesa; syn Muzy). Długotrwały, wydawałoby się okrutny sposób obróbki lnu, ale także winogron lub żyta, a nawet pieczenia chleba (od ziarna do bochna chleba, przez ogień) — był i jest kojarzony z cierpieniami Boga oraz ludzi, a opowieść o takich działaniach może ratować życie opowiadających.

Eisler poświęca akapit opowieści Andersena, wskazując nieznany kontekst — piosenek śpiewanych w papierniach, działających w Europie od 1320 roku. Przypomina poemat Karla von Holteia z Obornik o lnie (z końca XVII wieku). Pokazuje ryciny egipskie, na których grajek Linos towarzyszy wyrywaniu lnu i koszeniu zboża sierpem. Dodaje, że dzikiego lnu nie wyrywano. Przypomina, że Święty Błażej był torturowany grzebieniami do lnu'

Jacek Liberiusz w wielu fragmentach Kazania trzeciego na tenże dzień [Wielki Piątek] wypowiada się na temat lnu, pytając na przykład, „która jest rzecz na świecie, co najwięcej złego od człowieka ucierpi, a najwięcej mu dobrego czyni [...]" (Liberiusz, 2014, s. 275) ${ }^{10}$. Metaforycznie przekonuje o Boskiej opiece nad człowiekiem od urodzenia do śmierci i jednocześnie mówi o wielkich cierpieniach Syna Bożego. Podobnie jak lniana tkanina otula człowieka w każdym momencie życia, a nawet może być papierem, tak Bóg towarzyszy w całym życiu, także wysłuchując modlitwy. „Jeśli len do papieru, do pisania, do suplik służy, którąż suplikę Bóg przyjmie bez Syna swojego?” (Liberiusz, 2014, s. 276). O męce Syna Bożego kaznodzieja opowiada współczująco, przypominając kolejne etapy zajmowania się rośliną, aby otrzymać płótno - „jako len, im go więcej tłuką i trapią, tym jest śliczniejszy i lepszy” (Liberiusz, 2014, s. 290).

7 https://andersen.sdu.dk/forskning/motiver/tekstmotiver_e.html?vid=93 [data dostępu: 5.03.2020].

${ }^{8}$ R. Eisler and W.L. Hildburgh, The Passion of the Flax. https://www.jstor.org/stable/1257742 ?Search [data dostępu: 5.03.2020].

9 Ewa Krawiecka interpretuje motyw lnu w liryce Kazimiery Iłłakowiczówny na szerokim tle, uwzględniając na przykład symbolikę rośliny w Biblii oraz tekstach o tematyce biblijnej, związek rzezi na Wołyniu z 1943 roku z lipcowym kwitnieniem lnu oraz ekonomiczną kampanię na rzecz uprawy lnu w międzywojniu (Krawiecka, 2017).

${ }_{10}$ file:///C:/Users/user/Downloads/Pasja_Chrystusa_-_kaznodziejskie_renarra.pdf [data dostępu: 5.03.2020]. 
Harry Rasmussen, który zajmuje się kosmologią i kosmologicznymi historiami, opublikował kilka esejów na temat opowieści Andersena, przedstawiając znaczenia utworów na czterech poziomach interpretacyjnych. W 2014 roku ukazała się interpretacja $L n u^{11}$. Autor przedstawia fabułę opowieści, zaznaczając, że po wszystkich przemianach len nie całkiem został zniszczony; pozostały iskierki, które można by uznać za duszę (pierwszy poziom znaczeniowy). Na drugim poziomie wymienia te utwory Andersena, w których czytamy o rozwijających podróżach i etapach rozwoju duchowego, w czym pisarz inspiruje się teorią Hansa Christiana $\theta$ rsteda. Z kolei trzeci poziom znaczeniowy dotyczy zbieżności historii lnu z biografią Andersena (dzieciństwo, cierpienia w szkole gimnazjalnej i dorosłym życiu, przemiany twórczości literackiej, pisanie baśni). Czwarty poziom znaczeniowy wiąże się z ciągle następującymi przemianami czy wcieleniami, połączonymi z cierpieniem (reinkarnacja), pragnieniami, głodem i nasyceniem, ze świadomością bądź z nieświadomością i akceptacją, rozwojem indywidualnym i w społeczności - w królestwie roślin i w świecie ludzi. Rasmussen komentuje także ostatnie zdanie Lnu o rozumieniu tekstu przez dzieci, podkreślając rolę wyobraźni i przywołując zakończenie Królowej Śniegu.

Porównajmy Len Andersena $\mathrm{z}$ opisem w arcydzielnym Traktacie o łuskaniu fasoli Wiesława Myśliwskiego. Bohater przypomina sobie, że w Wigilię leżał na stole lniany obrus. Pamięta też i o tym opowiada, jak przebiegały wszystkie czynności, które wykonywała matka, związane z sianiem, obróbką, przędzeniem i tkaniem lnu. Opis Myśliwskiego skłania do refleksji nad pamięcią, przedmiotem, polską wsią, pracowitością i religijnością jej mieszkańców oraz ich szacunkiem dla tradycji (Fiedorczuk, 2020, s. 133-144). Dostrzec można pieczołowitość w odtwarzaniu przeszłości i czułość wobec tego, co było kiedyś. W książce Myśliwskiego opis cechuje się realizmem, a roślina jest uprawiana dla ludzi, jest dla nich użyteczna. Andersen napisał historię z elementami fantastyki, skupiając uwagę na roślinie i przypisując jej emocje, przemyślenia czy postawy, które mógłby przejawiać człowiek.

Wigilia zawsze zaczynała się od zapalenia świeczek na choince. Potem matka nakrywała stół białym obrusem. [...] O, to nie był taki zwykły obrus. Jedynie do Wigilii go matka nakrywała. Sama go utkała, wyszyła, z przeznaczeniem że tylko do Wigilii. A każdy wiedział, ile staranności ten obrus matkę kosztował. Len sama zasiała, i to na najlepszym kawałku ziemi. Zasiała rzadko, aby do każdej łodygi słońce dochodziło. Potem co dzień wychodziła patrzeć, jak rośnie. Ledwo jakiś chwaścik zaczynał z ziemi wystawać, dobierała mu się od razu do korzenia. Tak że gdy ten len urósł, dorodny był, mówię panu. Sama go sierpem zżęła ${ }^{12}$. O, właśnie nie wiedział pan, co to sierp. Sierpem dlatego, żeby nie

${ }^{11}$ H. Rasmussen, The fairy Tale "The Flax" — Seen in the Four Significance Levels. 2014 [data dostępu: 5.03.2020].

${ }_{12}$ Dziwi użycie sierpa; być może autor powieści pamięta wykorzystywanie tego narzędzia, ale $\mathrm{w}$ wielu innych tekstach mowa o wyrywaniu rośliny z korzeniami. 
połamać łodyg. Potem długo sechł na słońcu, potem jeszcze w stodole. A potem związany w wiązki, zabity kołkami, moczył się w Rutce, gdzie najbystrzejszy nurt. I znów sechł. Potem na międlicy go wymiędliła. Ale już nie będę panu objaśniał, jak wyglądała taka międlica. W innych stronach mówiło się paździerznica. Grubsze czy krótsze włókna od razu odrzucała. A ile potem było jeszcze przebierania, czesania, nie wyobraża pan sobie. Aż zostawała sama pajęczyna. Tak babka mówiła przy każdej Wigilii, że z pajęczyny ten obrus utkany.

Płótno, kiedy już utkała, kilka razy prała i suszyła. A było słońce, w słońcu rozścielała na trawie, aby jeszcze bardziej zbielało. Choć trudno sobie wyobrazić, żeby mogło być bielsze. Całe niemal lato, dzień w dzień, jeśli tylko było słońce, w tym słońcu rozścielała. I dopiero zimą zabrała się do wyszywania. [...] Cały rajski ogród wyszyła.

Myśliwski, 2018, s. 135-136

Maria Konopnicka napisała w 1902 roku baśniową historię o początkach uprawy lnu i wyrobu płótna. W opowieści Jak to ze lnem było ziarna lnu, które podarował chciwemu królowi starzec, potraktowane zostały jak prawdziwe złoto i wielki skarb, chociaż nie stało się tak od razu. Dzięki właściwościom włókna lnianego można było uszyć ubranie dla wielu ludzi. Poznawczy, dydaktyczny i literacki charakter utworu pozytywistycznej pisarki jest oczywisty (Konopnic$\mathrm{ka}, 1997)^{13}$.

Do Lnu powstawały ilustracje czarno-białe i barwne. Niekiedy Len wydawany był oddzielnie. Zwrócę uwagę na dwie książki: sprzed osiemdziesięciu lat i współczesną.

Bart van der Leck (1876-1958), członek holenderskiej grupy artystycznej De Stijl (1917-1931), przygotował w 1941 roku wyjątkowe, wyrafinowane artystycznie wydanie Lnu (HetVlas). Zaprojektował zgeometryzowaną czarną czcionkę, złożoną z linii prostopadłych. Każda karta ozdobiona była różnej wielkości prostokątami w kolorach grupy (czerwony, niebieski, żółty). Na większości stron znajdowały się także rysunki (z drobnych kreseczek) postaci ludzkich, w tym Sokratesa $^{14}$. W tekście i rysunkach dominowały więc linie proste, co świadczyło o wyjątkowym uporządkowaniu.

W wydawnictwie Kropka Kreska ukazała się pięćdziesięciostronicowa książeczka dla dzieci z opowiedzianym i zilustrowanym Lnem Andersena (Andersen, 2020). Wyróżnia się kolorem okładki i stron, które przypominają szary papier. Delikatne ilustracje złożone są z kresek i kropek w kilku barwach, na przykład niebieskiej, żółtej, zielonej i brązowej. Na stronach jest na ogół kilka linijek tekstu, tworzących wypowiedzenie, oraz ilustracje. Są pewne różnice w porównaniu z tłumaczeniem Sochańskiej, tym bardziej że Len jest opowiedziany, a nie przy-

13 Zob. projekt lekcji dla nauczania początkowego. http://projekt.noweskalmierzyce.pl/wp-con tent/uploads/2015/Jak_to_ze_lnem_bywa\%C5\%82o-1 [data dostępu: 5.03.2020].

${ }^{14}$ https://risdmuseum.org/art-design/collection/flax-het-vlas-20037\#content_section--des cription--1072346 [data dostępu: 5.03.2020]. 
toczony w całości. Przykładowo: płatki lnu są jak skrzydła motyla (nie mola), „kołki w płocie” są po prostu „płotem”; inne są słowa krótkiej piosenki - „Z kołowrotka ruchem / Ginie szczęście kruche”, pojawia się „warsztat tkacki”; zamiast „żony pastora” mówią „kobiety”. Nieco inaczej napisane jest zakończenie - nie ma zmiany liczby, nie mówi len, lecz mówią „niewidzialne istotki”: „To jest najpiękniejsze! My o tym już wiemy i jesteśmy najszczęśliwsze!”. Po ostatnich słowach: „Dzieci niekoniecznie muszą rozumieć wszystko” umieszczono ikonkę uśmiechu. Historia zmieniającego się lnu jest opowiedziana lojalnie wobec tekstu pisarza, ale bardziej nowoczesnym językiem, który lepiej trafi do młodszych czytelników. Książeczka warta jest polecenia.

W Wężyczynie koło Mińska Mazowieckiego Krzysztof Chojnacki i Genowefa Tkaczyk nakręcili w 1978 roku dokumentalny film ${ }^{15}$. Na filmie pokazano wszystkie etapy obróbki lnu w powiązaniu z porami roku, czyli wysiew - na wiosnę, zrywanie (wyrywanie z korzeniami), roszenie, odziarnianie, moczenie, suszenie - $\mathrm{w}$ lecie, międlenie (gniecenie, łamanie, aby oddzielić paździerze od łyka), tarcie, klepanie i czesanie - jesienią, oraz zimowe przędzenie lnu na kołowrotku i uzyskanie nitki. Na filmie można zobaczyć, jak używane są takie narzędzia, jak klepacze do lnu, międlice, cierlice, szczotki, kołowrotek; można się także przekonać o wspólnotowym charakterze zajęć przy lnie oraz poznać rozmaite wierzenia i przysłowia ${ }^{16}$.

Powstało kilka animacji filmowych opowieści Andersena. Joanna Jasińska-Koronkiewicz (reżyseria, plastyka, animacja) stworzyła m.in. techniką animacji malarskiej adaptację $L n u$. Film jest piękny, bajecznie kolorowy, poetycki, z elementami spoza tekstu, np. siew ziarna, motyle, tęcza (na niebie i w otwartym egzemplarzu książki Andersena) i bocian, fragment rękopisu, okładka „Andersen”, samolot (anachronizm), wzlatujące nad kominem literki. Wyraźnie zaznaczono zmiany w pogodzie (słońce, ciemne chmury i ulewny deszcz). Można film oglądać $\mathrm{z}$ audiodeskrypcją, napisami (tłumaczenie B. Sochańskiej) i językiem migo$\mathrm{wym}^{17}$. W filmie namalowano elementy $\mathrm{z}$ tekstu, dodając im twarze (upersonifikowane słońce, kołki płotu, główki lnu, kawałek płótna, bokserki, kartki papieru). W narracji zachowano najważniejsze zdania $\mathrm{z}$ tekstu. Niektóre elementy powtórzono, np. kolejne etapy przemiany lnu. Film jest piękną adaptacją, lojalną wobec tekstu pisarza i dostosowaną dla dzieci z niepełnosprawnościami.

Motyw lnu można znaleźć na obrazach. Impresjonistyczny obraz Pole lnu Edgara Degasa przedstawia rośliny w pagórkowatym krajobrazie i wśród drzew, traw oraz kwiatów ${ }^{18}$. Na trzech innych obrazach malarze przedstawili kobiety zajmujące się przygotowaniem lnianej przędzy: Henryk Rodakowski w 1859 roku

${ }^{15} \mathrm{http}: / /$ ethnomuseum.pl/blog/len-z-wezyczyna/ (blog Małgorzaty Jaszczołt — koordynatorki projektu Muzeum w terenie) [data dostępu: 5.03.2020].

${ }^{16}$ https://www.youtube.com/watch?v=IkNrbrehdeo [data dostępu: 5.03.2020].

${ }_{17} \mathrm{http}: / /$ tvsfa.com/108-len/ [data dostępu: 5.03.2020].

${ }^{18}$ https://www.wikiart.org/en/edgar-degas/field-of-flax-1892 [data dostępu: 5.03.2020]. 
Chłopka międlaca len ${ }^{19}$, w 1877 roku John William Waterhouse sportretował neapolitańską prządkę (The Neapolitan Flax Spinner) ${ }^{20}$, a Wilhelm Leibl namalował Przadki (1892) ${ }^{21}$.

Kajetan Sosnowski (1913-1986) wykonywał od połowy lat siedemdziesiątych XX wieku obrazy szyte z płótna lnianego i bawełnianego. Do jednego z cykli dołączył takie wyjaśnienie:

Len i bawełna to bezpośrednie produkty przemiany materii zachodzącej w roślinie, jej wymiany między ziemią a słońcem, przy której powstaje tlen, tak niezbędny dla naszej egzystencji. Katalipomeny stały się hołdem dla doskonałości natury - ku uwadze i refleksji widza ${ }^{22}$.

Cykl, nawiązując w tytule do greckich słów „zachować, „uchronić”, ma przesłanie ekologiczne, a „Skupienie na naturalnej strukturze lnu czy bawełny, rysunku wątku i osnowy ma tu istotny, niemal kosmologiczny sens”23. Można by powiedzieć, że przed takim obrazem stoi bohater wiersza Płótno Adama Zagajewskiego, zastanawiając się, czym jest wypełniony obraz, co przedstawia; snując refleksje o sztuce, życiu, wyobraźni i śmierci:

Stałem w milczeniu przed ciemnym obrazem, przed płótnem, które mogło zamienić się w płaszcz, w koszulę, w chorągiew, lecz stało się kosmosem. $[\ldots]$

Zagajewski, 2010, s. 139

W słowach upersonifikowanego lnu można dostrzec takie elementy postawy życiowej, jak pogodzenie z losem, cierpliwość w znoszeniu cierpienia, ufność w przyszłość, wdzięczność (Bogu) za dobre chwile, a może też jakąś naiwność. Uważna, wnikliwa lektura opowieści Andersena, lojalna wobec tekstu, ale i wykraczająca poza tekst, prowadzi do dostrzeżenia bogactwa i głębi znaczeń oraz do wieloaspektowego interpretowania i dobierania różnorodnych kontekstów. Wszystko to pozwala czytelnikowi docenić kunszt pisarza, a zarazem doznać przyjemności czytelniczej. I jeszcze cytat, który kończy poruszający esej Tadeusza Sławka, a który mógłby stanowić zwięzłe podsumowanie wątków opowieści

${ }_{19} \mathrm{http}: / /$ cyfrowe.mnw.art.pl/dmuseion/docmetadata?id=2929\&show_nav=true [data dostępu: 5.03.2020].

${ }^{20}$ https://gallerix.org/album/Waterhouse/pic/glrx-1752868981 [data dostępu: 5.03.2020].

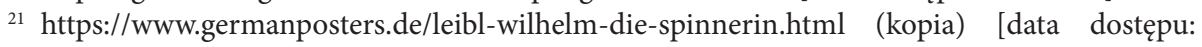
5.03.2020].

${ }^{22}$ Cytat ze strony https://culture.pl/pl/tworca/kajetan-sosnowski [data dostępu: 5.03.2020].

${ }^{23}$ Ostatnia wystawa artysty w galerii Raster. http://rastergallery.com/wystawy/michal-budnykajetan-sosnowski-uklad-rownowartosciowy/ (18 I-29 II 2020) [data dostępu: 5.03.2020]. 
Len: „[...] dwie strony cierpienia: zła, żalu i rozpaczy (po stronie »nie«), ale także nadziei i przemiany (po stronie »tak«)” (Sławek, 2019, s. 107).

\section{Literatura}

Andersen H.Ch., 2020, Len, Wojtiuk B., Baka M., opowiedziała, [b.m.w.]. Andersen H.Ch., 2006a, Baśnie i opowieści, Sochańska B., przeł., t. 1, Poznań. Andersen H.Ch., 2006b, Baśnie i opowieści, Sochańska B., przeł., t. 2, Poznań. Andersen H.Ch., 2006c, Baśnie i opowieści, Sochańska B., przeł., t. 3, Poznań. Fiedorczuk J., 2020, Pod słońcem, Kraków.

Filipowicz U., 2006, Len, w: Leończuk J., red., Wiersze znad Narwi i Niemna. Białostocczyzna - Grodzieńszczyzna. Antologia poezji dla dzieci, Szwed W., przeł., Białystok. Konopnicka M., 1997, Jak to ze lnem było, Wrocław.

Krawiecka E., 2017, Lniana symbolika $w$ wybranych utworach Kazimiery Iłłakowiczów$n y$, w: G. Różańska, red., Między sacrum a profanum. Rozważania i dylematy, Kraków, s. 253-263.

Liberiusz J., 2014, Kazanie trzecie na tenże dzień [Wielki Piątek], w: Gruchała J.S., Panuś K., wyd. i oprac. Kazania pasyjne, Kraków, s. 273-300.

Miernik A., 2015, Domeny wyobraźni: Andersen i Jung, Kraków.

Myśliwski W., 2018, Traktat o łuskaniu fasoli, Kraków.

Sławek T., 2019, „Ja bolę”. Boleść i terapia, w: Ganczar M., Gielata I., Ładoń M., Fragmenty dyskursu maladycznego, Gdańsk, s. 89-107.

Zagajewski A., 2010, Wiersze wybrane, Kraków.

\section{Źródła internetowe}

file://C:/Users/user/Downloads/Pasja_Chrystusa_-_kaznodziejskie_renarra [data dostępu: 5.03.2020].

http://allinfo.space/2018/10/19/the-paper-cuts-of-hans-christian-andersen/ [data dostępu: 5.03.2020].

https://books.google.pl/books?id [data dostępu: 5.03.2020].

https://culture.pl/pl/tworca/kajetan-sosnowski [data dostępu: 5.03.2020].

http://cyfrowe.mnw.art.pl/dmuseion/docmetadata?id=2929\&show_nav=true [data dos-

tępu: 5.03.2020].

http://ethnomuseum.pl/blog/len-z-wezyczyna/ [data dostępu: 5.03.2020].

https://gallerix.org/album/Waterhouse/pic/glrx-1752868981 [data dostępu: 5.03.2020].

http://projekt.noweskalmierzyce.pl/wp-content/uploads/2015/Jak_to_ze_lnem_bywa-

\%C5\%82o-1.pdf [data dostępu: 5.03.2020].

http://rastergallery.com/wystawy/michal-budny-kajetan-sosnowski-uklad-rownowar tosciowy/ (18 I-29 II 2020) [data dostępu: 5.03.2020].

http://teatratofri.pl/wp-content/uploads/2017/02/Len_recenzja_Small_Size_Days_2017 [data dostępu: 5.03.2020].

http://tvsfa.com/108-len/ [data dostępu: 5.03.2020].

https://www.germanposters.de/leibl-wilhelm-die-spinnerin.html [data dostępu: 5.03.2020]. 
https://www.jstor.org/stable/1257742?Sne\&ab_segments=0\%2Fbasic_SYC5055ntents [data dostępu: 5.03.2020].

https://www.wikiart.org/en/edgar-degas/field-of-flax-1892 [data dostępu: 5.03.2020]. https://www.youtube.com/watch? $\mathrm{v}=\mathrm{IkNrbrehdeo} \mathrm{[data} \mathrm{dostępu:} \mathrm{5.03.2020].}$

Rasmussen H., The Fairy Tale "The Flax" - Seen in The Four Significance Levels. 2014. https://risdmuseum.org/art-design/collection/flax-het-vlas-20037\#content_section-description--1072346 [data dostępu: 5.03.2020].

Ewa Ogłoza - doktor habilitowana, literaturoznawca w Instytucie Literaturoznawstwa na Uniwersytecie Śląskim w Katowicach; zajmuje się wieloaspektowo dydaktyką języka polskiego oraz literaturą dla dzieci i młodzieży; autorka książki Wokół opowieści Hansa Christiana Andersena. O radości czytania (2014) oraz wielu artykułów naukowych.

e-mail: ewa.ogloza@us.edu.pl 